\title{
ENGLISH LANGUAGE DIASPORA AND THE HIT-AND-MISS EXPERIMENTATION WITH ENGLISH CURRICULUM IN BANGLADESH
}

\author{
Mr. Md. Azizul Haque \\ Stamford University Bangladesh \\ Email:aziz_stmfd@yahoo.com
}

\begin{abstract}
Despite the common diasporic origin English in Bangladesh is neither a native nor a second language, but a foreign language, in countries like India and Pakistan, English is used as the second language. The chronological history of English in Bangladesh has both political as well as social elements, which influence the learning of English at every level of education. In the mid-90s there was a growing demand from the educationists in the country to change the English curriculum as per 'needs analysis', and the curriculum is restructured aligning with the communication needs and the syllabus was largely transformed into a communicative one. Yet research explores that the needs are not served for the learners tend to bypass the cognitive part of the language learning - thus failing to communicate properly. Now, in the second decade of the new millennium English curriculum along with other subjects has been made 'creative' at pre-tertiary level, but debates are still on to evaluate whether the system complies with the current practices prevailing within the institutional premises. The total picture thus presents a very confusing answer to the questions why all these efforts are being futile and why the English language teaching fails to touch the three main domains of learning - the cognitive, the affective and the psychomotor. The current study wants to explore whether such experiments with the curriculum and the dilemma of receiving or rejecting the idea of acculturation with largely an anti-colonial mindset hinder the desired performance of the language.
\end{abstract}

Keywords: English language Diaspora, hit-and-miss experimentation, curriculum, Bangladesh

\section{INTRODUCTION}

Current English Diaspora suggests four subtypes-i) English sprouting from England and spreading to the British Isles; ii) English that sailed to America in $17^{\text {th }}$ Century and settled in North and central America; iii) English that has been carried on to the colonies and established as the official language of communication, and finally; iv) English that has spread to countries which were not colonies of England, like China. The spread of English Language in Bangladesh falls into the third category where English as a diaspora is a direct result of colonization. So, this language has a particular background. The language policy of the colonial power in British India was based on Lord Macaulay's Education Minutes of 1835 . This policy aimed at forming "a class who may be interpreters between us (the British) and the millions we (the British) govern, a class of persons Indian in Blood and color, but English in taste, in opinions, in moral and in intellect" (Macaulay 1835, cited in Aggarwal, 1983). Macaulay in his minutes in 1835 stressed the importance and necessities of the education that would be given to the natives through the medium of English. He identified some objectives of such education. The objectives were designed to serve the interest of the master, not of the subjects. Thus, the primary objective of teaching English in the Indian subcontinent was to produce a class of people having the taste and outlook of an English man. The objectives of teaching English are thus very clearly defined. 
Following the legacy of British colonization the mode of study and the nature of the curriculum from primary to tertiary level was so far teacher-centered grammar translation method, popularly known as GTM. However, as most of the students of our postliberation Bangladesh are found unable to use English language effectively in different circumstances other than writing contexts, Communicative Language Teaching (CLT) was introduced in Bangladesh in the 1990s. (Teaching Quality Improvement in Secondary Education Project, Module-1, 2006). The aim of this approach is to develop learners' four skills, namely speaking, writing, reading and listening. It is thought to be a new approach to teaching English in Bangladesh at all levels. Bangladesh being a monolingual country, and as English is considered as a foreign language (Teaching Quality Improvement in Secondary Education Project, Module-1, 2006), inputs and resources like trained teachers, communicative teaching materials; and financial, infra-structural and management facilities are rigorously required to make the whole enterprise a success. The people learn English in order to speak to the people from other countries, to do business, to do diplomatic jobs, for higher studies, and also to use in courts, in trade and commerce, in civil and military administrations etc. The necessity of learning English is never debated. So English is introduced as a compulsory subject on the school curriculum. English is compulsory from play group to tertiary level. The students of our country have no option but to study English as a subject. Quader (2003:127) states: "CLT had been introduced at the S.S.C and H.S.C levels towards the end of the 90s, while next text books had been written for both levels for teaching through this method. The books were a source of worry for the teacher at H.S.C level as they had neither been trained in CLT nor briefed on using such books.
English has become the modern lingua franca, i.e. the language of communication among speakers of other languages. As such, English can help bridge communication gaps across cultures. The last decade or so has been marked by a new phenomenon called globalization. This has a profound impact on different domains of life such as social, political and economic. It has also experienced significant changes in the communication dynamics of the world. English language is the most crucial gear of this new communication euphoria. English as a subject is of paramount importance in equipping the students to take up the challenges of the competitive survival and growing globalization in developing countries. The global distributions of English are often described in terms of three contexts such as English as a Native Language (ENL), English as a Second Language (ESL) and English as a Foreign Language (EFL). Thus the diffusion of English throughout the world is seen in territories, viz., ENL territories, ESL territories and EFL territories (McArthur, 1996). Although officially English is a national second language in Bangladesh, this does not make Bangladesh an ESL country, as there exists mainly a non-Anglophone environment outside the English classrooms. The CLT (Communicative language teaching) situation in Bangladesh is thus comparable to other EFL countries (Karim, 2004).

Richards et al. (2001) suggest that "a foreign language is a language which is taught as a school subject but which is not used as a medium of instruction in schools nor as a language of communication within a country, a second language is a subject which is not a native language in a country but which is widely used as a medium of communication and which is usually used alongside another language or languages" (108). But when the diasporic dilemma presents an issue of linguistic imperialism, English in a country like Bangladesh might have silently suffered from a negative attitude of rejection or denial. 
Since the early 1990s, linguistic imperialism has attracted attention among scholars of applied linguistics. In particular, Robert Phillipson's (1992) Linguistic Imperialism, has led to considerable debate about its merits and shortcomings. Phillipson found denunciations of linguistic imperialism that dated back to Nazi critiques of the British Council, and to Soviet analyses of English as the language of world capitalism and world domination.As language is part of culture, linguistic imperialism is often manifested in the context of cultural imperialism. Such a view treats English not as 'lingua franca', rather as 'lingua cuckoola'-language that lays eggs at other language's nest only to drive the native in the end. We might have also suffered from this cultural and linguistic insecurity resulting in the denial to accept the English language as essential tool for global adaptability. These, however, are all hypothetical assertions which require empirical study to substantiate with necessary data.

\section{OBJECTIVE}

The main objective of this research is to investigate the main challenges of implementing English curriculum and to specify the socio-political dilemma in fixing the accurate roadmap in establishing a holistic system of education to confirm the substantial growth in developing a culture of teachinglearning English in Bangladesh. It is also required to prescribe an appropriate curriculum format that will address the needs of the nation. More specifically, the research objective includes a proper diagnosis of the current scenario of learning English to offer a workable policy to ensure the best practices of language learning context.

\section{LITERATURE REVIEW}

Lev Semyonovich Vygotsky's concept of the 'zone of proximal development', often understood to refer to the way in which the acquisition of new knowledge is dependent on previous learning, as well as the availability of instruction, discusses how (language) learning happens. The theory is popularly known as ZPD from which the idea of 'Scaffolding' has been derived to support the learning of the learners. Qin Xiao's "How Communicative Language Teaching Became Acceptable in Secondary School in China", published in TESL Journal 10 (6), has described in the Chinese context how the fourth type of Diasporic experience now helps China learning English Language. Here the article focuses on the need to have standard English in the pedagogical context. This, however, is an appeal that reflects the changes in teaching methodologies and approaches adopted due to national policy which might have an analogous understanding of the English language pedagogy in Bangladesh as we also had similar experimentation with our curriculum and teaching. It is an interesting area of research where we may find the diasporic culture of these two countries-Bangladesh and China. Narayan Krinshaswamy's English Teaching in India, published from T. R. Publications, Madras discusses the issues of Language Diaspora in India and how the effect is felt in the socio-psychological level. $H$ Douglas Brown's Teaching by Principles: An Interactive Approach to Language Pedagogy is a widely acclaimed methodology text used in teacher education programs around the world. This user-friendly textbook offers a comprehensive survey of practical language teaching options which will provide an insight to the proposed title. Howel\&Wolet in their article "An Analysis of School Based English Curriculum" states the necessity of curriculum alignment so that the primary needs of language are served with respect to teaching and assessment.

"English in the Expanding Circle-A third Diaspora?", published in the prestigious journal of English, Asian Englishes, Vol 11 (1), p.36-50, is an attempt to discuss the spread of English as a language throughout the world 
and it also focuses on how the non-native speakers of English contribute to the development of English language. The essayist, Debbie Ho, a professor of English at University of Brunei Darussalam, claims that there are actually three diasporas of English Language - the native, the colonized and the one exercising the language for its status as lingua franca. This discussion, however, is full of appreciation of the language being used widely in the world, most notably by the 'expanding circle' of the third Diaspora where the language users are motivated by the growing demands of this universal language in the field of science, arts and commerce. Though the argument lacks updated information about the language and of Diaspora, it, in another way, glorifies the colonial aspects of today's language imperialism. Here, Ii is notable that the writer is only concerned with the physical expansion of the English users in the expanding circle, but does not focus on the quality of the English being used at commerce or even at pedagogical circles.

Bambose's (1998) "Torn between the Norms: Innovation in World Englishes", published in World Englishes, Vol-17, discusses issues of native and non-native English norms, with reference to the two great professors of English-Lord Randolf and Professor BrajKachru's ideas of 'liberation linguistics,' 'deficit linguistics' and alliterative catch phrases like'Quirk concern,' 'Kachru catch' (Quirk, 1985，1990; Kachru，1985, 1991). Bambose's call for andonormative standard of English, rather, ignited the debate of linguistic imperialism. In the growing change of the need and application of English language, this, however, is not at all acceptable to look for total acculturation or nativisation. English in today's context is more practiced by countries like India, China, Philippines and in other ESL or EFL countries. For Bangladesh, it is yet to have a consensus among the policy makers and academics to decide over the status and approach of the English pedagogical aspects.Kingsley Bolton (2005) in World English journal, Vol: 24, Issue: 1, has his remark: "Over the last three or four decades, the term 'World Englishes' (WE) has been widely used to refer to localized forms of English found throughout the world, particularly in the Caribbean, parts of Africa, and many societies in Asia. Today, it is generally accepted that promotion and acceptance of the world Englishes paradigm has fundamentally changed the study of English linguistics, particularly from a sociolinguistic perspective." discuss the ways in which the world Englishes paradigm has recently begun to shift, in order to accommodate the new realities of English in a globalising world, as well as academic and intellectual responses to such changes. This it does specifically by examining the sociolinguistic backgrounds and experiences of two groups of young people in South China, and the complicated multilingual countries like India and Philippines. His article, "Where WE Stands: Approaches, Issues, and Debate in World Englishes" sets out to review current approaches to world Englishes from a range of perspectives, from English studies to sociolinguistics, applied linguistics, lexicography, 'popularizers' and critical linguistics. It then proceeds to consider current debates on English worldwide and world Englishes, noting the recent criticisms of the world Englishes approach from rhetoric of a critical linguistics ironically at odds with the realities of many educational settings. What would be the stand of Bangladesh with respect to that issue of debate is a necessary area of research. Over the span of four and a half decade Bangladesh education Ministry has worked on this syllabus and curriculum design, but it seems now to have entangled into a dilemma of seeting a compatible curriculum equally implementable in our local context. It is no doubt that we will learn English, but how we will learn this language — lingua franca — of 
global communication is yet to be finalized as far as the central policy is concerned.

David Johnson's “Teaching Culture in Adult ESL: Pedagogical and Ethical Considerations", however, has made an attempt to address this cultural integration or interference by putting the issue this way, "Experienced teachers of adult English as a Second Language (ESL) know that learning about culture is part of learning English. Adult ESL learners themselves understand that language learning consists of more than the ability to understand new linguistic structures. Indeed, the coding and decoding of communicative acts requires an understanding and appreciation of the cultural context in which they occur."(Johnson, 2005) Yet criticisms and words of caution by Auerbach (1993), Canagarajah (1999), Phillipson (1993), and Skutnabb-Kangas (2000) regarding the teaching of culture should not be overlooked. These scholars have criticized ELT professionals and materials alike for their hegemonic tendencies, particularly in their representations of the target culture. They claim many ESL pedagogical practices are hegemonic in that mainstream American and British cultures are portrayed as dominant and superior to the culture of the second language (L2) student. The ramifications of these criticisms go beyond simply being culturally sensitive; they can affect acquisition efficacy and ultimately the proficiency levels attained in the second language.

Learners are affected in their language acquisition by their perception of the target culture. If a language learner perceives the target culture as well as his native culture in positive terms, then proficiency in the L2 is enhanced (Brown, 2000). However, as Schumann (1976) notes, there are two possible "bad" language-learning situations in regards to cultural perceptions. If an L2 learners perceive the target culture as dominant or if the L2 learners perceive their own culture in competition with the target culture, then acquisition will be hindered.

Unfortunately, teaching culture necessitates exclusionary practices that could be interpreted as hegemonic. In much the same way that teaching English requires a program or instructor typically to choose a particular language model (American, British, Indian, etc.) to the exclusion of others, teaching culture requires that only parts of the target culture be included. Instructors lack time and expertise to include all relevant aspects (if it were even possible to determine what all the relevant aspects were). The dilemma then for ESL teachers is to include and integrate culture in their language curriculum without hegemonizing. But, how does an instructor discuss culture without imposing it? This study examines how one adult ESL program addresses this question by presenting the results of a qualitative study.Sandra Lee McKay (2006) in RELC Journal brings this discussion into consideration for curriculum design and development. Her article "EIL Curriculum Development" argues that current changes in the nature of English and English language learners warrants a re-evaluation of two widely accepted notions of ELT curriculum development, namely, that the goal of English learning is native speaker competence and that native speaker culture should inform instructional materials and teaching methods. Recognizing the current status of English as an international language (EIL), the author describes central features of an international language and how these influence the relationship between language and culture. The paper then proceeds to demonstrate how native speaker models and culture need to be carefully examined in reference to EIL curriculum development.Jennifer Jenkins and Barbara Seidlhofer suggest how the results of new research into how 'non-native' speakers of English use the language must change the way it is taught (Jenkins, JenifEr and Seidlhofer, 
Barbara 2010). They added that in fact, it is even claimed that a European variety of English, sometimes labeled "Euro-English", is in the process of evolving to serve as a European lingua franca. As yet, however, this new variety of English has not been described, largely because it is at such an embryonic stage in its evolution. All we can say with any degree of certainty is that English as a lingua franca in Europe (ELFE) is likely to be some kind of European-English hybrid which, as it develops, will increasingly look to continental Europe rather than to Britain or the United States for its norms of correctness and appropriateness.

However, as long as there is no sound empirical basis for a description of how the language is actually used, the forms ELFE will take will remain an object of speculation. Barbara Seidlhofer's (2001) "Closing a Conceptual Gap: The Case for a Description of English as a Lingua Franca.", published in the world famous International of Applied Linguistics, Suggests that the teaching of English worldwide is tied to native speaker norms and argues that although this orientation is often recognized as inappropriate and counter-productive, it persists because discussions about global English on the metalevel have not been accompanied by a necessary reorientation in linguistic research. She has rightly put the matter of diversity of the standard performance which is now conceptually termed as diasporic nativisation.

A. F. M. Rabbi, in his essay "Primary Education in Bangladesh: Viability of Achieving Millennium Development Goals," has thoroughly pointed out the target and achievement of our education policy. He urges the necessity to train teachers with necessary supply of instruments to achieve the goal of our curriculum. Chowdhury's "a case study for the communicative approach in our classroom" published in Journal of the Institute of Modern Language shows light on the current scenario of the CLT in Bangladesh. Abdur Rahman's "Education Innovation and Cultural Change" published in The Dhaka Universities studies shows a few of the cultural confusion in learning English as a foreign language. National Curriculum and Textbook Board's Compulsory Curriculum is studied and would also require more scanning to infer the gaps in the field. Doman's "Current Debates in SLA" published in Asian EFL Journal, Vol 7, raises questions about the existing curriculum of the Asian countries and proposes for a workable curriculum of English. However, no substantial work is done at home or abroad on this issue of the hegemonic confusion of the Diaspora of English in this part of the land. A few TV talks and seminars are igniting the issue of diasporic confusion of the English Language curriculum at large in our country. So, further study on this issue is required to have a comprehensive understanding to fix the future directive for ensuring better teaching-learning of English in the country.

\section{METHODOLOGY}

The research conducted was primarily qualitative in nature. Existing socio-cultural and socio-political scenario of the country with respect to the English language learning have been studied to investigate the validity of the research question that whether there is any connections between English diasporic traditions and the curriculum we have in the country having failed to teach this language up to satisfaction. However, quantitative tools like questionnaire survey for learners and teachers are also used to collect opinions of the major stakeholders. So, the mixed method is apprehended to be more appropriate to draw conclusion of the study.

\section{RESULT}

Out of eight questions in the questionnaires, the first one asked both to teachers and students are replied in different ways. The question is a common question whether the English curriculum in Bangladesh (school to tertiary) is up to the mark. About 
$60 \%$ of the students disagreed while only $35 \%$ of the teachers disagreed on this point. This obviously represents a diverse opinion on an issue which might reflect on the diverse needs of the stakeholders. The second question to the students is teachers' responsibility in the failure of achieving students' language proficiency, where again the diversity of opinion is noteworthy. $70 \%$ students blame teachers for not carrying out their task properly, whereas teachers in the second question about students' responsibility in failure of language learning are responded in the similar fashion. $50 \%$ of the teachers strongly agree, $15 \%$ agree and the remaining $35 \%$ either disagree or strongly disagree to hold students responsible for their performance. Question number three is on teachers' readiness and awareness about the major domains of teaching-learningcognitive, affective and psychomotor, and whether the current curriculum and teaching covers these major areas of learning. Here students and teachers are close in their responses. About $75 \%$ teachers and students agree that all these three domains are not equally touched by our current practices as far as the English language learning is concerned. Students and teachers in question four opine that repeated change in policies have negative effect on students' performance as both these stakeholders see this as a hit-and-miss experimentation with students. Students here are $90 \%$ on strong agreement, while teachers also opine the same where $80 \%$ agreeing with the statement. This gives a major focus on the exploration of the cause behind the poor English language performance. More lights are shed on the issue by the next question which inquires about the adequate training of the teachers to deal with the English curriculum. Here again teachers and students are in the same platform to agree with the point that teachers are provided with the curriculum without necessary training. Whether (English language) teachers are well trained is viewed with disagreement by $70 \%$ of the teachers, where students are $80 \%$ to disagree too. Students and teachers in the next question also agree that socio-political factors influence the education policy of our country. Majority of the respondents point at the change of the government playing a negative role that affects the English language learning of the country. In question seven, about $75 \%$ of teachers and $85 \%$ of students agree with cultural factors influencing English language learning. Madrasa (religious school) education, division of English and Bengali medium, and the general fear of learning English are noted as responsible for creating confusion in understanding the right need of English language learning. The last section of the questionnaire has asked for opinion about how to overcome the dilemma or confusion about English language learning. The main points that have been recommended by the respondents are summarized below:

a) Adequate teachers' training is required, especially in the institutions in the rural setting

b) Major confusions about the importance of learning English are to be addressed nationally through adequate seminars and symposiums

c) Repeated experimentations should be stopped with curriculum policies and a general conscientious should be reached at political level

d) English should be practiced not as a foreign language, but as the second language in Bangladesh. And English should be mandatory at all levels and media of education.

\section{CONCLUSION}

The data interestingly shows an association of socio-cultural dilemma with the English curriculum in Bangladesh. This socio-cultural dilemma might be viewed as the diasporic dilemma where English as a language is always seen a product of colonization. This, however, 
is setting a ground for not welcoming a language of the oppressor. This overt political stand of seeing English from such viewpoint of linguistic imperialism would of course take us back to the early $19^{\text {th }}$ Century situation where the Muslims of this subcontinent found all evils in English as language of the non-believers. Surely, we will not commit the same old mistake in this $21^{\text {st }}$ Century. Let there be a curriculum with specific learning objective and testable learning outcome to meet the market needs of this century and let our government be prudent enough to treat English as a property of the global community to meet the needs of the $21^{\text {st }}$ Century learners.

\section{REFERENCES}

Aggarwal, J. (1983). Landmarks in the history of modern Indian education.Delhi: Vikas.

Bamgbose, A. (1998). Torn Between The Norms: Innovations in World Englishes, 17(01), 1-14.

Bolton, K. (2005). Where WE stands: approaches, issues \& debates in World Englishes. World Englishes, 24(01), 6983.

HO, D. G.E. (2008). English in the Expanding Circle - A third Diaspora?.Asian Englishes. 11(01), 36-50.

Jenkins, J. and Seidlhofer, B. (2001). Bringing Europe's lingua franca into the classroom in Pulverness, A. (ed.): IATEFL 2001 Brighton Conference Selections (pp. 8790). Whitstable: IATEFL.

Johnson, D. (2005). Teaching culture in adult ESL: pedagogical \& ethical considerations. TESL-EJ, 9(01), 1-9.

Kachru, B. (1985). "Standards, codification \& sociolinguistic realism: the English language in the outer circle" in Quirk, R.\& H.G. Widdowson (eds.): English in the World (pp. 11-30).

Cambridge: Cambridge University Press.

Karim, K. M. R. (2004). Teachers' perceptions, attitudes and expectations about
Communicative Language Teaching (CLT) in post-secondary education in Bangladesh (A Thesis for the Degree of Master of Arts, Department of Curriculum and Instruction, University of Victoria). Retrieved from https://dspace.library.uvic.ca/bitstream/ha ndle/1828/560/karim_2004.pdf?sequence $=1$.

McArthur, T. (ed.). (1996). The Oxford companion to the English language

(abridged edition). Oxford: Oxford University Press.

McKay, S. (2006). EIL curriculum development. In R. Rubdy \& M. Saraceni (Eds.), English in the world: Global rules, global roles (pp. 114-129). London, UK: Continuum.

National Curriculum and Text Books Board (2006).Teaching English. Dhaka: Teaching Quality Improvement in Secondary Education Project.

Phillipson, R. (1992). Linguistic imperialism. Oxford: Oxford University Press.

Quader, D.A. (2003). Teacher Training for Teachers of English. Journal of the Institute of Modern Language. Dhaka: Dhaka University Press.

Quirk, R. (1986, 1990). Words at work: lectures on textual structure. Singapore: NUS Press.

Richards, J. C \& Rodgers T. S. (2001). Approaches and methods in language teaching. (2nd Ed). Cambridge: Cambridge University Press.

Seidlhofer, B. \& Jenkins, J. (2003). English as a lingua franca $\&$ the politics of property. In C. Mair (Ed.), The politics of English as a world language: New horizons in post colonial cultural studie (pp.139-154). Amsterdam: Rodopi.

Seidlhofer, B. (2001). Closing a conceptual gap: the case for a description of English as a lingua franca. International Journal of Applied Linguistics, 11(02), 135- 158. 


\section{Appendix:A}

\section{Teachers' Feedback Questionnaire}

Class / Classes You Teach in:

Year of Experience:

Name of institution (optional):

Your Contact / E-mail (optional):

The following questions try to identify teachers' opinions on English curriculum from a sociolinguistic point of view. Your answers will be kept confidential and meant only for research ends with high ethical sensitivity.

Instruction: Please put tick mark on your choice.

1. English curriculum in our country is up to the mark.
a. Strongly Agree
d. Disagree
b. Agree
e. Strongly Disagree
c. Neutral

2. Students' are primarily responsible for not succeeding in language (English) learning.
a. Strongly Agree
d. Disagree
b. Agree
e. Strongly Disagree
c. Neutral

3. Teachers are well aware of the major domains, like cognitive, affective and the psychomotor of language learning.
a. Strongly Agree
d. Disagree
b. Agree
e. Strongly Disagree
c. Neutral

4. Repeated change in policies and curriculum affect the teaching-learning of English in our country.
a. Strongly Agree
d. Disagree
b. Agree
e. Strongly Disagree
c. Neutral

5. Teachers are well trained for teaching the curriculum they are provided with by NCTB or UGC.
a. Strongly Agree
d. Disagree
b. Agree
e. Strongly Disagree
c. Neutral

6. Are there any socio-political factors that have influenced the language policy of our country? If 'yes' please specify.
a. Yes
b. No

7. Are there any socio-cultural factors that have influenced the language policy of our country? If 'yes' please specify.
a. Yes
b. No

8. Please give your suggestion(s) about how to overcome the problems of English curriculum:

Students' Feedback Questionnaire

1. English curriculum in our country is up to the mark.
a. Strongly Agree
d. Disagree
b. Agree
e. Strongly Disagree
c. Neutral

2. Teachers' are primarily responsible for not successfully teaching language (English).
a. Strongly Agree
d. Disagree
b. Agree
e. Strongly Disagree
c. Neutral 
3. Teachers are well aware of the major domains, like cognitive, affective and the psychomotor of language learning.
a. Strongly Agree
d. Disagree
b. Agree
c. Neutral
e. Strongly Disagree

4. Repeated change in policies and curriculum affect the teaching-learning of English in our country.
a. Strongly Agree
b. Agree
d. Disagree
e. Strongly Disagree
c. Neutral

5. Teachers are well trained for teaching the curriculum they are provided with by NCTB or UGC.
a. Strongly Agree
d. Disagree
b. Agree
e. Strongly Disagree
c. Neutral

6. Are there any socio-political factors that have influenced the language policy of our country? If 'yes' please specify.
a. Yes
b. No

7. Are there any socio-cultural factors that have influenced the language policy of our country? If 'yes' please specify.
a. Yes
b. No

8. Please give your suggestion(s) about how to overcome the problems of English curriculum: 